\title{
PELATIHAN PEMBUATAN MP-ASI WHO BERBASIS PANGAN LOKAL BAGI KADER POSYANDU DAN IBU BADUTA DI DESA SIDOSARI
}

\author{
Dewi Sri Sumardilah ${ }^{1}$, Antun Rahmadi ${ }^{1}$, Anggun Rusyantia ${ }^{1 *}$ \\ ${ }^{I}$ Dosen Jurusan Gizi Poltekkes Tanjungkarang, Bandar Lampung \\ Jl. Soekarno Hatta No.1 Bandar Lampung \\ Penulis Korespodensi : rusyantia_anggun@yahoo.com
}

\begin{abstract}
Abstrak
Salah satu upaya untuk meningkatkan kesehatan dan gizi anak adalah dengan memberikan makanan yang terbaik bagi Baduta. Jika bayi dan anak usia 6-24 bulan tidak memperoleh cukup gizi dari MP-ASI, maka akan mengakibatkan gangguan pertumbuhan dan kurang gizi. Desa Sidosari adalah salah satu desa binaan Poltekkes Tanjung Karang. Berdasarkan hasil pengkajian gizi Balita yang dilakukan sebelumnya ternyata masih dijumpai beberapa masalah gizi khususnya pada kelompok umur Baduta. Penyebab utamanya adalah masih terbatasnya pengetahuan ibu tentang gizi Baduta dan keterampilan ibu dalam menyiapkan makanan untuk memenuhi kebutuhan gizi dengan pangan lokal yang tersedia. Kader Posyandu yang selama ini sudah berperan aktif dirasakan masih lemah dalam memberikan edukasi ASI dan MP-ASI. Padahal kader Posyandu sangat potensial perannya sebagai agen perubahan. Kegiatan Pengabdian Kepada Masyarakat Pelatihan Pembuatan MP-ASI WHO Berbasis Pangan Lokal Bagi Kader Posyandu dan Ibu Baduta telah dilaksanakan pada tanggal 27 dan 28 Nopember 2017. Pelatihan hari pertama dilaksanakan di Posyandu Melati dan hari kedua di Balai Dusun Simbaringin dengan jumlah peserta pelatihan sepuluh orang. Hasil evaluasi akhir terjadinya peningkatan pengetahuan dan keterampilan peserta sebesar 68,9\%. Untuk membentuk perilaku gizi yang baik pada keluarga diperlukan kegiatan pendampingan keberlanjutan.
\end{abstract}

Kata kunci: Baduta, Gizi, MP-ASI WHO

\section{Pendahuluan}

Usia di bawah dua tahun (Baduta) merupakan kelompok rawan gizi yang akan menentukan kualitas hidup selanjutnya. Oleh karena itu pemenuhan gizi pada kelompok tersebut harus diupayakan dengan sungguh-sungguh. Salah satu upaya untuk meningkatkan kesehatan dan gizi anak adalah dengan memberikan makanan yang terbaik bagi Baduta. WHO \& UNICEF (2003) merekomendasikan pemberian makanan yang baik dan tepat bagi bayi dan anak Baduta adalah: (1) mulai menyusu dalam 1 jam setelah lahir; (2) pemberian ASI secara eksklusif sampai usia 6 bulan; (3) memberikan Makanan Pendamping ASI (MP-ASI) mulai usia 6 bulan; (4) Meneruskan pemberian ASI sampai Usia 2 tahun atau lebih.

MP-ASI harus diberikan setelah anak berusia 6 bulan karena pada masa tersebut produksi ASI semakin menurun sehingga supply zat gizi dan ASI tidak lagi memenuhi kebutuhan gizi anak yang semakin meningkat. Apabila terlambat dalam waktu pemberian makan ini maka akan menyebabkan masalah gizi bagi bayi dan anak. Berdasarkan penelitian yang dilakukan oleh Datesfordate dkk (2017) bahwa terdapat hubungan pemberian makanan pendamping air susu ibu (MPASI) dengan status gizi bayi pada usia 6-12 bulan di wilayah kerja Puskesmas Bahu Manado. Hal ini menunjukkan bahwa ibu yang selalu memperhatikan kesehatan bayinya dan memberikan MP-ASI bergizi kepada bayi dapat mempercepat pertumbuhan dan perkembangan bayi sehingga status gizi bayi menjadi lebih baik.

Keadaan ini memerlukan penanganan tidak hanya dengan penyediaan pangan, tetapi dengan pendekatan yang lebih komunikatif sesuai dengan tingkat pendidikan dan kemampuan masyarakat. Selain itu, ibu-ibu kurang menyadari bahwa setelah bayi berumur 6 bulan memerlukan MP-ASI dalam jumlah dan mutu yang semakin bertambah sesuai dengan pertambahan umur bayi dan kemampuan alat cernanya.

Desa Sidosari adalah salah satu desa binaan Poltekkes Tanjung Karang. Desa Sidosari berada di 
kabupaten Lampung Selatan yang meskipun tidak terlalu jauh dengan ibukota provinsi akan tetapi masih dijumpai permasalahan dalam hal pemberian makanan pada Baduta.

Berdasarkan hasil pengkajian gizi Balita yang dilakukan di desa tersebut pada kegiatan Pengabdian Kepada Masyarakat (Pengabmas) periode sebelumnya ternyata masih dijumpai beberapa masalah gizi khususnya pada kelompok umur Baduta. Dalam hal status gizi, masih terdapat $12,8 \%$ Batita gizi kurang (BB/U), Batita pendek+sangat pendek (TB/U) sebesar $22,1 \%$ dan Batita kurus+sangat kurus (BB/TB) sebesar 11,3\%. Penyebab langsung dari adanya masalah gizi tersebut adalah karena asupan gizi yang tidak memadai. Hal ini dapat dilihat dari proporsi Baduta yang kurang mengkonsumsi energi sebesar $60,6 \%$ dan kurang mengkonsumsi protein sebesar $43,8 \%$.

Salah satu kontributor terhadap rendahnya asupan energi dan protein pada anak adalah pemberian makanan yang kurang memadai (Kumar, et al., 2006). Dua indikator yang dapat digunakan untuk menilai rendahnya asupan energi dan protein pada Baduta adalah proporsi IMD (inisiasi menyusu dini) masih rendah yaitu $52,4 \%$ dan pemberian ASI eksklusif baru mencapai 31,5\%. Dalam hal MP-ASI masih dijumpai pemberian yang terlalu dini yaitu pada usia 1 bulan dan ada yang terlambat yaitu pada usia 7 bulan.

Hasil pengukuran pengetahuan gizi Baduta diperoleh gambaran bahwa ibu Baduta yang tergolong berpengetahuan baik sebesar $12,8 \%$ dan selebihnya $(87,2 \%)$ berpengetahuan sedang dan rendah. Seperti diketahui bahwa tingkat pengetahuan ibu tentang gizi berpengaruh terhadap perilaku ibu dalam memilih makanan untuk seluruh anggota keluarga khususnya anak balitanya yang berdampak pada asupan gizi (Supariasa, 2015).

Praktik pemberian makan yang baik dan tepat sangat penting untuk kelangsungan hidup, pertumbuhan, perkembangan, kesehatan dan gizi bayi dan anak.Terjadinya gangguan pertumbuhan khususnya pada kelompok Baduta di kedua desa mitra menunjukkan belum optimalnya pemberian makanan (ASI dan MP-ASI). Penyebab utamanya adalah masih terbatasnya pengetahuan ibu tentang gizi Baduta dan keterampilan ibu dalam menyiapkan makanan Baduta untuk memenuhi kebutuhan gizinya dengan sumberdaya yang tersedia.

Kader Posyandu merupakan tenaga kesehatan yang paling dekat dengan masyarakat yang selama ini berperan aktif dalam penimbangan balita dan pencatatan/ pengisian KMS, namun masih dirasakan lemah dalam memberikan edukasi ASI dan MP-ASI. Kader kesehatan masyarakat bertanggungjawab terhadap masyarakat setempat serta pimpinan-pimpinan yang ditunjuk oleh pusatpusat pelayanan kesehatan. Di harapkan mereka dapat melaksanakan petunjuk yang diberikan oleh para pembimbing dalam jalinan kerja dari sebuah tim kesehatan (Meilani, 2009).

Berdasarkan penelitian yang dilakukan oleh Dewi (2017), bahwa salah satu peran kader posyandu di lihat dari sisi diseminasi informasi/inovasi adalah berupa tindakan kader posyandu kepada masyarakat melalui komunikasi tatap muka, antar personal, komunikasi antar kelompok, bahkan komunikasi dengan bantuan media. Oleh karena itu dalam mendukung pengembangan skill/ keterampilan para kader perlunya pelatihan pengembangan diri di bidang lain.

Tujuan umum dari kegiatan Pengabmas adalah meningkatkan pengetahuan dan keterampilan kader dan ibu Baduta dalam dalam mengolah makanan anak. Tujuan khusus dari kegiatan ini adalah :

1. Tersedianya panduan pelatihan pengolahan makanan anak baduta

2. Tersedianya resep makanan anak baduta yang bersumber dari bahan pangan lokal

3. Terjadinya peningkatan pengetahuan dan keterampilan peserta pelatihan

Bagan alir kegiatan dapat dilihat pada Gambar 1.

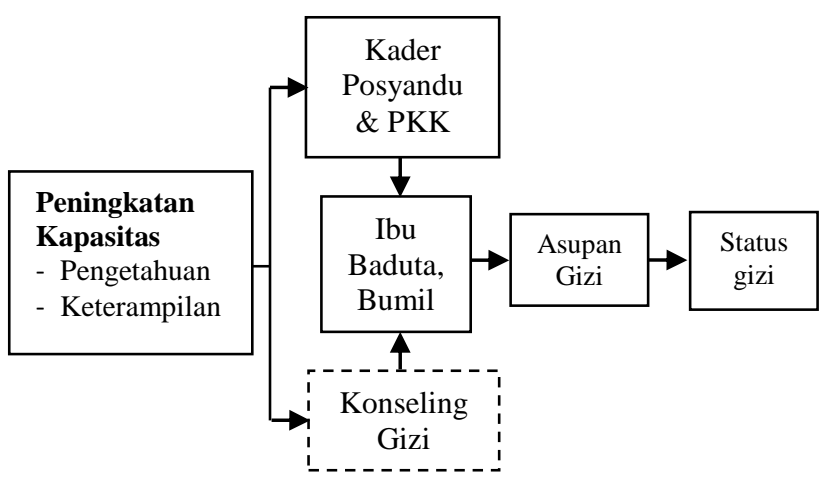

Gambar 1. Bagan alir kegiatan

\section{Metode}

A. Waktu, Lokasi dan Peserta Kegiatan

Kegiatan pelatihan dilaksanakan selama dua hari yaitu tanggal 27 dan 28 Nopember 2017. Hari pertama bertempat di Posyandu Melati dan hari kedua di Balai Dusun Simbaringin. Sasaran utama 
kegiatan pelatihan adalah kader Posyandu, kader PKK dan Ibu Baduta.

\section{B. Bahan dan Metode}

Metode yang digunakan dalam kegiatan ini meliputi ceramah, tanya jawab, dan demonstrasi. Ceramah dan tanya jawab dilakukan pada saat proses pelatihan teori. Metode demonstrasi pengolahan makanan dilakukan ketika praktik mengolah makanan anak baduta. Kegiatan ini melibatkan dosen dan mahasiswa yang berbagi tugas sebagai fasilitator, pembimbing praktik dan demonstrasi serta kepanitiaan. Bahan dan alat yang digunakan untuk menunjang pelaksanaan pelatihan ini yaitu modul pelatihan, laptop, speaker aktif, kertas plano, spidol, kompor dan tabung gas, bahan makanan, peralatan makan dan peralatan memasak. Modul yang digunakan dalam pelatihan ini menggunakan metode MP-ASI WHO yang diadopsi dari Modul Pelatihan Manajemen MP-ASI Berbasis WHO yang diselenggarakan oleh PERINASIA tahun 2016.

\section{Hasil dan Pembahasan}

Pelatihan hari pertama dilaksanakan dengan memberikan materi mengenai permasalahan gizi baduta, pentingnya asupan gizi pada baduta, permasalahan dalam pemberian makan baduta dan metode MPASI berbasis WHO. Peserta tampak antusias menyimak materi dan memiliki keingintahuan yang cukup besar tentang materi yang disampaikan. Hal ini terlihat dari banyaknya inetrupsi berupa pertanyaan langsung yang disampaikan oleh peserta saat narasumber menyampaikan materi untuk mempertajam pemahaman peserta.

Pemberian materi juga diselingi dengan memberikan tips dan contoh-contoh praktis yang relevan dengan permasalahan orangtua dalam pemberian makan pada anak, misalnya bagaimana mengatasi masalah anak yang melakukan Gerakan Tutup Mulut (GTM), pemberian makan pada balita sakit serta mensiasati anak yang susah makan. Selain itu materi juga diselingi oleh kegiatan ice breaking guna melakukan penyegaran dan meningkatkan semangat peserta untuk menerima materi selanjutnya.

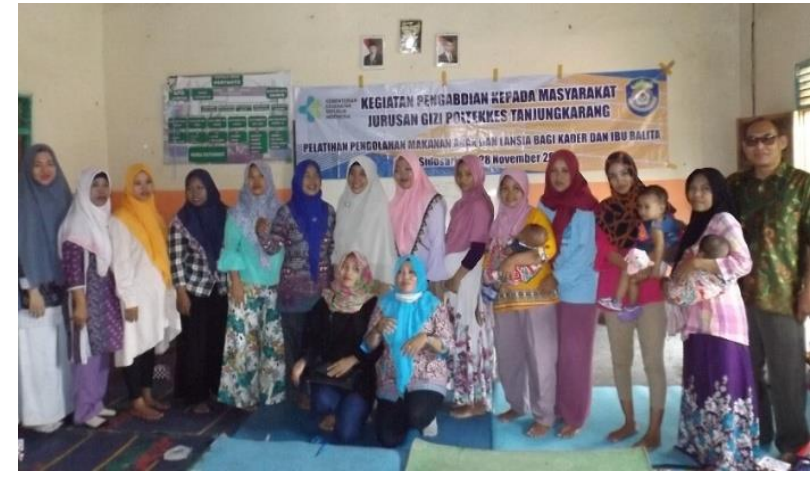

Gambar 2. Foto Bersama Tim Pengabdian dengan Peserta dan Ibu Kepala Desa

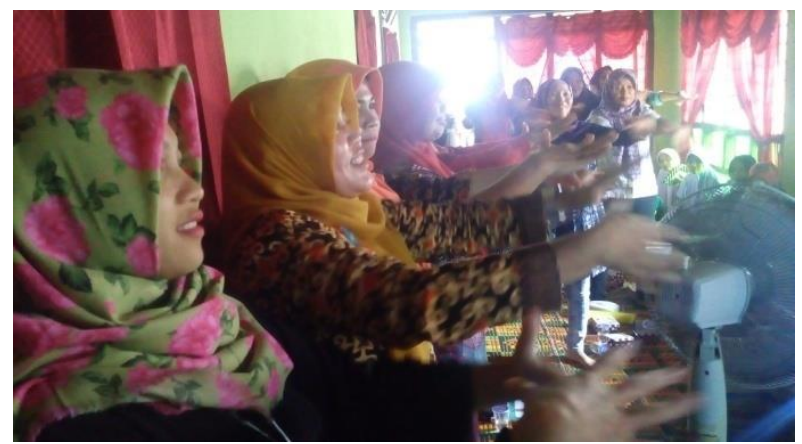

Gambar 3. Kegiatan Ice Breaking saat jeda materi

Pelatihan hari kedua dilaksanakan dengan melakukan praktik memasak makanan baduta dan melakukan demo tekstur MPASI. Dalam praktik ini, peserta telah dibagikan resep menu bayi sesuai tahapan tekstur dan usia yaitu resep untuk bayi usia 6 - 6,5 bulan dengan tekstur kental; 6,5 - 9 bulan dengan tekstur lumat; $9-12$ bulan dengan tekstur cincang dan > 12 bulan dengan tekstur makanan keluarga. Pelaksanaan praktik masak ini dibantu oleh mahasiswa sebagai asisten dan peserta pelatihan dengan didampingi oleh fasilitator menggunakan panduan resep yang telah diberikan.

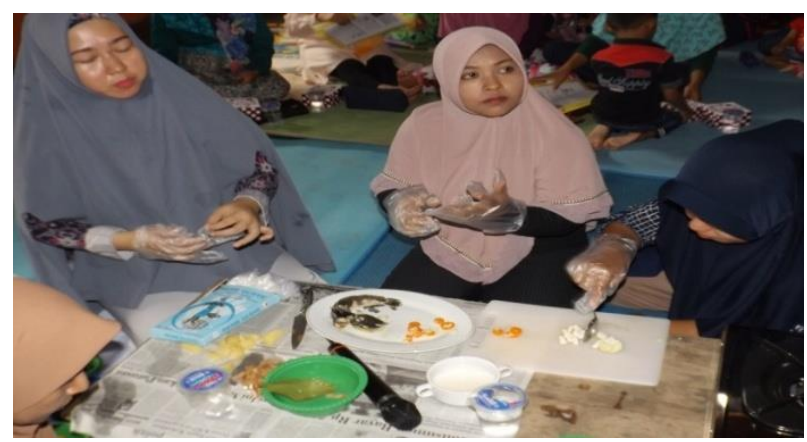

Gambar 4. Praktik Demo Tekstur Pembuatan MPASI oleh Perwakilan Peserta 


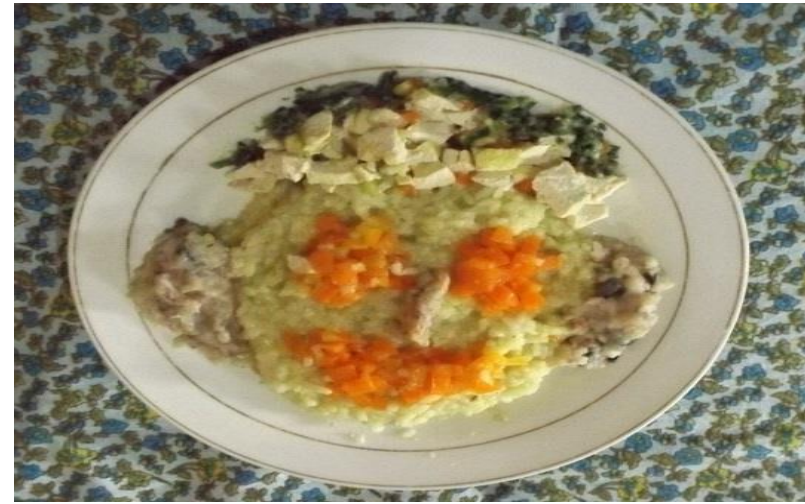

Gambar 5. Hasil Demo Praktik Peserta Menu Bayi usia 9-12 bulan

Bahan pangan lokal yang diberikan dalam resep adalah bersumber dari potensi bahan pangan lokal yang banyak tersedia di Desa Sidosari dengan harga yang terjangkau antara lain singkong, ubi jalar, ikan lele, tahu, pepaya dan sayur mayur seperti bayam dan wortel. Di akhir sesi materi praktik hari kedua, dilakukan kegiatan tambahan berupa forum konseling bagi peserta yang ingin berkonsultasi seputar permasalahan gizi ibu hamil dan baduta.

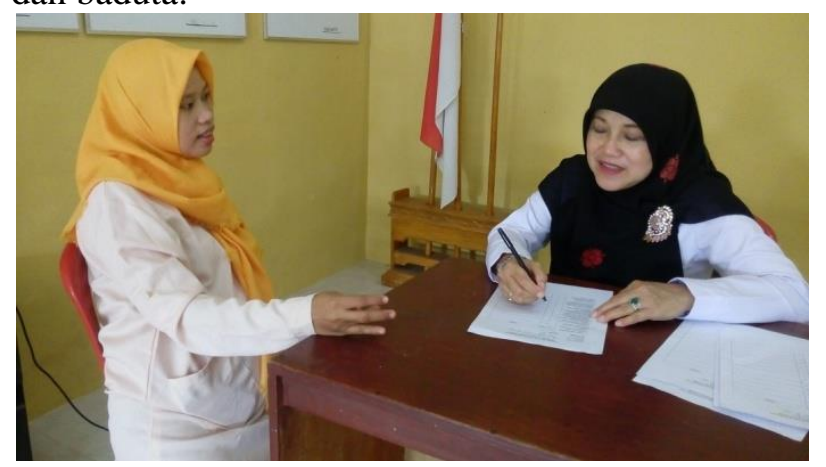

Gambar 6. Konsultasi Gizi oleh Fasilitator

Sebelum dan setelah pemberian materi, peserta diberikan kuesioner pre-test untuk mengetahui prevalensi pengetahuan peserta mengenai gizi baduta dan MPASI. Rata-rata skor pre-test, post-test dan prevalensi peningkatan pengetahuan peserta dalam memahami materi yang telah disampaikan disajikan dalam tabel 1.

Berdasarkan hasil rekapitulasi nilai skor pretest dan post test dari peserta pelatihan diperoleh prevalensi peningkatan pengetahuan peserta sebesar 68,9 \%. Hal ini menunjukkan bahwa peserta memahami materi yang disampaikan dengan cukup baik.
Tabel 1. Rekapitulasi Skor Peningkatan Peserta

\begin{tabular}{ccccc}
\hline $\begin{array}{c}\text { Pesert } \\
\text { a }\end{array}$ & Pre-test & $\begin{array}{c}\text { Post- } \\
\text { test }\end{array}$ & $\begin{array}{c}\text { Selisi } \\
\mathbf{h}\end{array}$ & $\begin{array}{c}\text { Peningkatan } \\
(\mathbf{\%})\end{array}$ \\
\hline 1 & 6 & 9 & 3 & 50.0 \\
2 & 7 & 12 & 5 & 71.4 \\
3 & 8 & 14 & 6 & 75.0 \\
4 & 7 & 10 & 3 & 42.9 \\
5 & 7 & 13 & 6 & 85.7 \\
6 & 7 & 11 & 4 & 57.1 \\
7 & 8 & 15 & 7 & 87.5 \\
8 & 9 & 15 & 6 & 66.7 \\
9 & 6 & 10 & 4 & 66.7 \\
10 & 7 & 13 & 6 & 85.7 \\
$\begin{array}{c}\text { Rata- } \\
\text { rata }\end{array}$ & $\mathbf{7 . 2}$ & $\mathbf{1 2 . 2}$ & $\mathbf{5}$ & $\mathbf{6 8 . 9}$ \\
\hline
\end{tabular}

\section{Kesimpulan dan Saran}

Berdasarkan hasil evaluasi diketahui bahwa secara umum kegiatan yang telah dilaksanakan telah mencapai tujuan umum yang ditetapkan yaitu meningkatnya pengetahuan dan keterampilan kader dan ibu Baduta dalam dalam mengolah makanan anak. Secara khusus capaian dari kegiatan adalah $\mathrm{t}$ tersusunnya pedoman pelatihan pengolahan makanan anak, tersusunnya resep makanan anak dan terjadinya peningkatan pengetahuan dan keterampilan kader rata-rata sebesar 68,9\%.

Untuk membentuk perilaku gizi yang baik pada keluarga diperlukan waktu yang lama sehingga perlu dilakukan kegiatan pendampingan keberlanjutan yang bersifat kontinu, oleh karena itu diharapkan kader yang telah dilatih dapat menjalankan perannya secara terus menerus khususnya dalam membina sasaran dalam hal penerapan gizi seimbang. Selain itu, perlu pembinaan berkelanjutan kepada kader agar memperoleh pembaruan pengetahuan dan keterampilan khususnya yang berkaitan dengan penerapan gizi seimbang agar mempunyai bekal yang cukup dalam memberdayakan gizi keluarga.

\section{Daftar Pustaka}

Datesfordate, A.H., Rina K., Julia V.R. 2017. Hubungan Pemberian Makanan Pendamping Air Susu Ibu (MP-ASI) dengan Status Gizi Bayi Pada Usia 612 Bulan di Wilayah Kerja Puskesmas Bahu Manado. e-journal Keperawatan (e-Kp) Volume 5 Nomor 2, Agustus 2017.

Dewi, D.S. 2017. Peran Komunikator Kader Posyandu dalam Meningkatkan Status Gizi Balita di 
Posyandu Nuri Kelurahan Makroman Kecamatan Sambutan Kota Samarinda. eJournal Ilmu Komunikasi, 5 (1) 2017 : 272-282 ISSN 2502597X.

Kumar, D., Goel, N.K., Mittal, P.C. et al., 2006. Influence of infant-feeding practices on nutritional status of under-five childrenIndian $\mathbf{J}$ $\begin{array}{llll}\text { Pediatr } & \text { (2006) } & \text { 73: }\end{array}$ doi:10.1007/BF02758565.
Meilani, N. Setiyawati, N. dan Estiwidani, D. S. 2009. Kebidanan Komunitas. Yogyakarta: Fitramaya.Yogyakarta

Supariasa, N.I.D., Bachyar, B. \& Fajar, I. (2012). Penuntun Status Gizi. Jakarta: EGC Penerbit Buku Kedokteran.

World Health Organization, UNICEF. Global strategy for infant and young child feeding. Geneva: World Health Organization;2003 